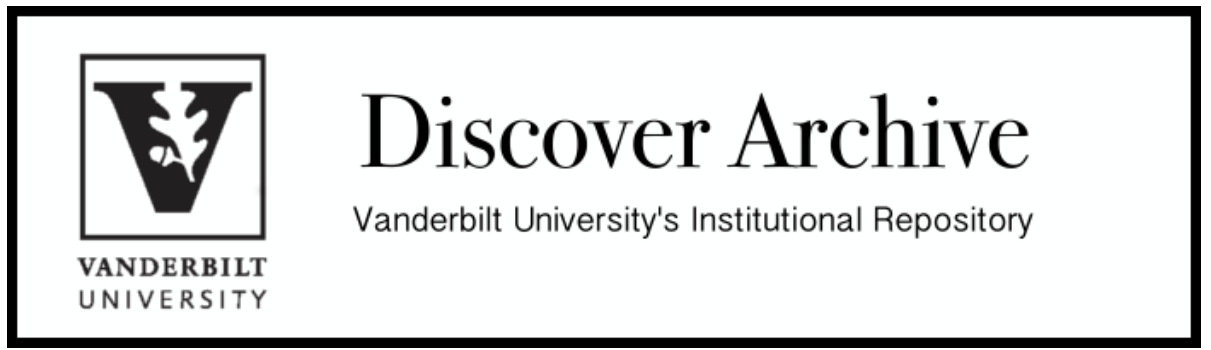

This work was originally published as: James D. Cox and Randall S. Thomas, Common Challenges Facing Shareholder Suits in Europe and the United States 6 European Company and Financial Law Review 348 (2009). 


\section{HEINONLINE}

Citation: 6 ECFLR 3482009

Content downloaded/printed from

HeinOnline (http://heinonline.org)

Wed Sep 18 13:06:50 2013

-- Your use of this HeinOnline PDF indicates your acceptance of HeinOnline's Terms and Conditions of the license agreement available at http://heinonline.org/HOL/License

-- The search text of this PDF is generated from uncorrected OCR text.

-- To obtain permission to use this article beyond the scope of your HeinOnline license, please use:

https://www.copyright.com/ccc/basicSearch.do?

\&operation $=$ go\&search Type $=0$

\&lastSearch $=$ simple\&all=on\&titleOrStdNo=1613-2548 


\title{
Common Challenges Facing Shareholder Suits in Europe and the United States
}

\author{
by \\ JAMES D. Cox* and RANDall S. Thomas $* * *$
}

Episodic and even sometimes systematic misbehavior by businessmen and corporate entities is ubiquitous. While Enron and WorldCom were the battle cries for corporate reform in the U.S. so it was with Abold and Parmalat across Europe. No country is free of concern that company officers will misbebave thereby injuring investors, consumers and destroying shareholder value. Thus, this symposium issue collects the recent experiences across Europe in strengthening sharebolder suits. Most recent legislative efforts in Europe, and hence the comments in the symposium, are focused on the derivative suit. Just as the American experience with class actions, reviewed separately in this symposium, ${ }^{1}$ is long and rich, it is also possible to draw upon the American experience to emphasize the challenges law reform faces on both sides of the Atlantic in energizing the derivative suit. The following addresses multiple themes that pervade the various articles exploring the derivative suit in Europe and hopefully provides a useful perspective drawn from the American experience with derivative suits.

$$
\text { Table of Contents } \quad \text { ECFR 2009, 348-357 }
$$

A. The mission of the derivative suit $\ldots \ldots \ldots \ldots \ldots \ldots \ldots \ldots \ldots$

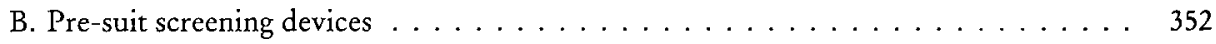

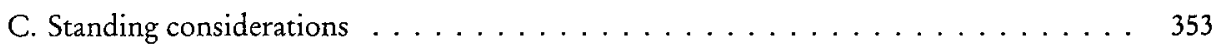

D. Losers pay . . . . . . . . . . . . . . . . . . . . . . 354

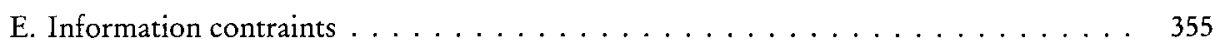

F. Conclusion-paving the way for the entrepreneurial lawyer $\ldots \ldots \ldots \ldots \ldots$

* Brainerd Currie Professor of Law, Duke University School of Law.

$\because *$ John S. Beasley II Professor of Law and Business, Vanderbilt University School of Law.

1 James D. Cox and Randall S. Thomas, Mapping the American Shareholder Litigation Experience: A Survey of Empirical Studies of the Enforcement of the U.S. Securities Laws, (2009). 


\section{A. The mission of the derivative suit}

We frequently romanticize the derivative suit as the little David taking on the Goliath, the management of a public company. Commentaries in this symposium refer frequently to the derivative suit possibly addressing negligent and wasteful management. ${ }^{2}$ At the same time, reports are provided that there are few such suits initiated within Europe and those that are crash on procedural shoals that cause them to at best be a stillborn, rather than a mighty, David. ${ }^{3}$

A different perspective of the derivative suit is that it has not a single focus but multiple ones. The least likely mission for the derivative suit is addressing management ineptitude. In the U.S., as in Europe, director judgments are surrounded by an extremely high presumption of propriety. ${ }^{4}$ This presumption is driven by the need to encourage legitimate entrepreneurial behavior, risk taking, and outsiders to serve as directors. In the much celebrated litigious and litigation-welcoming culture of the U.S. we can find extremely few instances of suits surviving pretrial motions where the suit's focus is managerial negligence or for that matter waste. ${ }^{5}$

We submit that the focus of discussion regarding the mission of the derivative suit should not be negligent misbehavior by officers, directors and controlling stockholders but rather self-dealing and intentional misconduct. This indeed is the experience in the U.S. Such a focus is especially appropriate in Europe. The symposium papers frequently emphasize the prevalence of the dominant

2 See e.g., Alexia Bertrand \& Arnaud Coibion, Shareholder Suits Against the Directors of a Company, against other Shareholders and against the Company itself under Belgian Law, at 11-12 (2009); Susanne Kalss, Shareholder Suits: Common Problems, different solutions and first steps toward a possible harmonization by means of a European Model Code, at 14-15 (2009); Arad Reisberg, Shadows of the Past and Back to the Future: Part 11 of the UK Companies Act 2006 (in)action, at 15 (2009).

3 See Paolo Giudici, Representative Litigation in Italian Capital Markets: Italian Derivative Suits and (if ever) Securities Class Actions, at 4 (2009)("the Italian Derivative action exists on paper, but not in the real world); Dario Latella, Shareholder Derivative Suits: A Comparative Analysis and the Implications of the European Shareholders' Rights Directive, at 14 (2009)("no theoretic model has been developed to explain the absence of derivative suits."); Reisberg, note 2, supra at 24-25 (speculating that past infrequency of derivative suits will not increase in light of continuing judicial skepticism of shareholder suits).

4 See generally John C. Coffee, Jr., Litigation and Corporate Governance: An Essay on Steering Between Scylla and Charybdis, 52 Geo. Wash. L. Rev. 789 (1984).

5 See Bernard Black, Brian Cheffins \& Michael Klausner, Outside Director Liability, 58 Stan. L. Rev. 1055 (2006). 
stockholder in European companies ${ }^{6}$ as contrasted with more diffuse ownership that is the norm in the U.S. and U.K. The presence of the dominant stockholder, coupled with weaker securities laws, provide a fertile ground for wealth to be transferred from the minority to the dominant stockholder through various related party transactions. This of course is the well known phenomenon of "tunneling." With the mission of the derivative suit so defined it is easier to consider how to strengthen its mission; if defined as a means of addressing negligent or improvident managerial decision making, the suit runs aground on the before-mentioned commercial concerns that underlie the high presumption of propriety that customarily enshrouds managerial decision making.

A further dichotomy that would be helpful in defining the mission for the derivative suit is the public-private divide offered by several commentators.? While the focus advanced above for the derivative suit within public companies is tunneling, in the private company it is minority oppression. For the latter the derivative suit can be just a governor on relations between majority and minority holders, but also a means for exit of the latter. That is, the well-understood problems of the private company are that there is no readily available share market that can provide an exit for the disgruntled minority holder ${ }^{8}$ and there are abundant opportunities for the majority holders to favor themselves. In this context, there is probably less reason to defer to the judgment of managers and greater reason to entertain suits by the minority so that the ultimate remedy is a judicially crafted exit such as a mandatory buyout. This at least is where the progressive thinking is in the U.S. where the emerging rule, now embraced by the American Law Institute, is to depart within the private ("close") corporation setting from the classic distinction between direct and derivative actions.

6 See Paolo Giudici, Representative Litigation in Italian Capital Markets: Italian Derivative Suits and (if ever) Securities Class Actions, at 4 (2009)(referring to continuing concerns of expropriations of minority shareholders and creditor interests by directors in response to dominant stockholder); Kalss, note 2, supra at 15.

7 See Kalss, note 2, surpa at 5-6.

8 See Bertrand \& Coibion, note 2, supra at 21-28 (2009)(describing the "exclusion" judicial proceeding whereby the majority can acquire the shares of the petitioning minority).

9 ALI, 2 Principles of Corporate Governance: Analysis and Recommendations $\$ 7.01$ (d)(1992)(excusing distinction between individual and corporate cause of action in close corporations upon the presiding court finding it will not expose the defendant to multiple suits, will not prejudice creditors, and will not interfere with the fair distribution of the recovery among interested parties). See generally James D. Cox \& Thomas Lee Hazen, Cox \& Hazen On Corporations $\$ 15.03$ at $905-06\left(2^{\text {nd }}\right.$ ed. 2003$)$. 
The above is not to suggest that the derivative suit is either an abundant or successful social mechanism in the U.S. While its presence is well-documented, its impact is distinctly within the private corporation setting. Even in the U.S. it appears sometimes to be on life support. ${ }^{10}$ What innervates the derivative suit is bestowing on it a mission that assures it will fail. The dominant view that shapes its procedural and substantive contours are that the derivative suit is above all else to be compensatory. Professor Paolo Giudici wisely emphasizes that one cannot separate compensation from deterrence. ${ }^{11}$ This perspective is certainly the case in the private company setting where an award to the minority shareholders not only makes them whole but also affirms the underlying substantive principle that guides shareholder relations so that others are not only aware of the principle but are reminded that should they misbehave they too will be sanctioned. ${ }^{12}$

But in the public company, where the focus of the derivative suit is likely to be self dealing, the magnitude of the harm caused by that misconduct is easily dwarfed by the market capitalization of the company on whose behalf the derivative suit is brought. ${ }^{13}$ This feature itself assures that even a successfully prosecuted derivative suit is not likely to boost the share value - the ultimate measure of gain within the public company setting. Further discounting the suit's effects are the litigation costs-those of both the suit's plaintiff and defendants all of which are likely to be drains upon the corporation itself. Thus, if we define the derivative suit's mission as compensatory we will find, certainly in the public company setting, that it frequently will not serve its mission. Indeed, so defined, the derivative suit is likely born into a life of failure. A far more hopeful career awaits the suit if we begin with a view that the derivative suit's mission is to pay its own way toward deterring misconduct.

10 For a careful empirical review of the incidence and experiences of shareholder litigation in the U.S., see Robert B. Thompson \& Randall S. Thomas, The Public And Private Faces Of Derivative Lawsuits, 57 Vand. L. Rev. 1747 (2004); Robert B. Thompson \& Randall S. Thomas, The New Look Of Shareholder Litigation: Acquisition-Oriented Class Actions, 57 Vand. L. Rev. 133 (2004).

11 See Giudici, note 6 supra.

12 See James D. Cox, The Social Meaning of Shareholder Suits, 65 Brook. L. Rev. 3 (1999); James D. Cox, Compensation, Deterrence, And The Market As Boundaries For Derivative Suit Procedures, 52 Geo. Wash. L. Rev. 745 (1984).

13 So it is that studies of outcomes of derivative suits focused on their impact on the firm's market price conclude they produce no detectable benefits. See Roberta Romano, The Shareholder Suit: Litigation Without Foundation?, 7 J. L. Econ. \& Org. 55 (1991); Daniel R. Fischel \& Michael Bradley, The Role of Liability Rules and the Derivative Suit in Corporate Law: A Theoretical and Empirical Analysis, 71 Cornell L. Rev. 261 (1986). 


\section{B. Pre-suit screening devices}

Derivative suits are a peculiar legal institution. They are suits brought on behalf of an inanimate entity, the company, but outside the typical decision making process by which the entity contemplates its actions, namely its board of directors. Most of the approaches addressing this concern that are described in this symposium focus on action by the stockholders at a general meeting. At one time, approval by the stockholders indeed was an important precondition to maintaining a derivative suit on behalf of a U.S. company; however, it has proven unwieldy so that seeking shareholder approval as a precondition to maintaining a derivative suit is either abandoned or excused in the U.S. ${ }^{14}$

The more prevalent screening mechanism for maintaining a derivative suit remains the board of directors. ${ }^{15}$ This obviously poses the serious challenge to the derivative suit since it is not likely that colleagues will favor the demand for suit made by the disgruntled stockholder when to do so is understood to subject a board or officer colleague to the burdens of litigation. ${ }^{16}$ Hence, the life of the derivative suit in the U.S. is in the relatively narrow confines of either instances in which judicial doctrine excuses a demand on the board of directors or in the earlier-described close corporation context in which suits are essentially characterized as direct actions. ${ }^{17}$ And, even when a demand is excused, there remains the prospect that the director voice will derail the suit via the board's power to create and staff a committee of the board to opine whether the continuation of the suit is in the corporation's best interests. ${ }^{18}$

A third possible screening device is conditioning suit on approval by a third party, for example a governmental agency. This approach faces at least two

14 See Cox and Hazen, note 9, supra at $\$ 15.06$.

15 See e. g., Federal Rule of Civil Procedure 23.1; Del. Ch. Ct. R. 23.1; N.Y.Bus. Corp. Law $\$ 626(c)$.

16 See James D. Cox \& Harry L. Munsinger, Bias in the Boardroom: Psychological Foundations and Legal Implications of Corporate Cohesion, 48 Law \& Contemp. Prob. 83 (1985).

17 Delaware defines these instances somewhat narrowly where the derivative suit's allegations raise a reasonable doubt that a majority of the board of directors is independent or that the decision that is the focus of the derivative suit is protected by the business judgment rule. See Aronson v. Lewis, 473 A.2d 805 (1984). The American Bar Association's Model Business Corporation Act which is followed in a sizable minority of the states pursues an approach of universal demand whereby a demand must be made on the board of directors in nearly all instances but subjects dismissal of the suit on consideration whether the company's response to the demand is in good faith after reasonable inquiry. See MBCA $\$ \$ 7.41-7.44$.

18 This device is customarily referred to as a special litigation committee. See e. g., Zapata Corp. v. Maldonado, 430 A.2d 779 (Del. 1981). 
hurdles. First, would the designated agency wish to have this responsibility as it places it in the center of a dispute that it may well lack sufficient experience or information to resolve whether the suit should be maintained. Second, why would an agency be better than a court in evaluating whether the interests of the corporation are likely to be advanced by the suit's continuance. ${ }^{19}$

While some screening device for a representative suit appears justified, we might wonder if the best approach lies outside the bias-ridden internal procedures of the corporation and with the presiding court. The on-going developments in the U.S. of "business courts" are based on the belief that a judicial officer who addresses on a regular basis commercial disputes can better handle those suits than can a judge whose experience spans the full range of issues that can come before courts. We can see in the U.S. greater power accreting to judges in the handling of the pre-screening device of the demand requirement. Thus, the protective wall for divining the corporate interest served by derivative suit in the U.S. increasingly is in the judge and not the board of directors.

\section{Standing considerations}

The most puzzling feature of some of the derivative suit procedures reported in this symposium is the requirement in some jurisdictions that limits suits to shareholders holding a specified amount of the company's shares. ${ }^{20} \mathrm{We}$ might believe such a requirement reflects the belief that only a substantial holder of shares will have a sufficient interest in the suit to prosecute the suit aggressively; the smaller the interest of a holder the less that person benefits from the suit's prosecution. By conditioning standing on the suit's plaintiff having some "skin" in the game, this standing requirement tacitly rejects the deterrent perspective of the derivative suit and also expressly overall distrust of the litigants. The latter is all the more puzzling in light that European

19 Thus, the German and U.K. systems appear to blend the thought of judicial expertise with the American universal demand requirement. See Latella, note 3, supra at 12; Reisberg, note 3 supra at 5 . The most intriguing of the third-party prescreening device is the French "pre-trial judicial investigation" described by Professor Bernard Grelon, Shareholder Lawsuits Against The Management Of A Company And Its Shareholders Under French Law, at 4-6 (2009).

20 See Betrand \& Coibion note supra at 13 (Belgian company can have suit brought on its behalf by holder of $1 \%$ of voting rights or holder of $€ 1,250,000$ ); Giudici, note 6 supra at 7 (discussing Italy's 2003 reduction in share holdings to $2.5 \%$ ); Grelon note 19 supra at 7-8 (French condition standing upon owning at least $5 \%$ of the registered capital); Kalss, note 2 supra at 16-17; Latella, note 3 supra at 10 (observing Spain conditions standing on owning at least $5 \%$ of the share capital). 
jurisdictions adhere to the loser pays principle in civil litigation. ${ }^{21}$ Moreover, even a small percentage ownership in a public company equates to a substantial investment on the part of the plaintiff; however, given the loser pays principle it is difficult to imagine that the ex ante cost-benefit-risk assessment by even such a substantial holder will justify suit. In combination these considerations point toward the most perplexing aspect of conditioning standing on a prescribed level of ownership: what does such a prescription accomplish that the natural assessment of costs, benefits, and related risks would not provide? Certainly a shareholder contemplating initiating a suit in the face of a jurisdiction's unwavering commitment to the loser pays principle can be expected to act rationally and will proceed with a suit only when the expectations of success are high. It is doubtful that requiring the holder's ownership percentage to meet a certain level adds much to the calculus.

America and Europe each require the derivative suit plaintiff to be a stockholder and in the U.S. there is the further requirement that to have standing to sue the plaintiff's holdings must have existed at the time of the occurrence of the misconduct that is the subject of the suit. ${ }^{22}$ Concern was expressed in one of the papers that standing would be lost if during the prosecution of the suit the plaintiff disposed of some of her holdings so that the ownership percentage declined below the stated minimum. ${ }^{23}$ While in the U.S. there is a requirement that the derivative suit plaintiff must be a stockholder throughout the suit (indeed, until judgment becomes final), this requirement does not prevent the suit's plaintiff from disposing of some of her shares so long as she retains at least one share until the suit's conclusion. We might consider whether either of these requirements are fully satisfying in a world in which derivatives (such as an put option) permit features of a security to be sliced and diced so that economic rights embodied in a share can be separated from legal ownership of the shares.

\section{Losers pay}

What truly separates the U.S. from the European (or for that matter the experiences outside of the U.S.) experience with shareholder litigation is the American Rule. This provides that litigants bear their own litigation costs so that the losing party, with but few exceptions, is not required to indemnify their successful opponents. It is the American Rule that best reflects the U.S.

21 The principle of loser pays and its implications for the derivative suit are discussed in the next section.

22 See Cox and Hazen, note 9 supra at $\$ 15.09$.

23 See Giudici note 6 supra at 5-6. 
commitment to the principle of providing access to justice. It is this rule that stimulates the growth of our judge-made law through long-shot suits. ${ }^{24} \mathrm{New}$ theories and novel arguments are stillborn in a world in which failure equates to paying your opponent's litigation costs. Fee shifting does occur in the U.S. but in the limited instance in which the presiding court believes there has been an abuse of discretion. ${ }^{25}$ Because of the strong commitment and long history of providing access to justice, such fee awards occur rarely. Moreover, in shareholder litigation, if successful or even if partially so in the sense of producing a benefit to the corporation, courts award fees to the plaintiff's counsel that are paid by the corporation on whose behalf the suit was maintained. ${ }^{26}$

There is much inertia around this issue on each side of the Atlantic so it is unlikely that the experiences drawn from our neighbors will alter the home legal landscape. Loser pays does appear to be an anomalous appendage where the suit has been approved by the stockholders. In this context, while such approval does not lead to the natural conclusion that the claims are legitimate or actionable, such approval can be seen as extending the imprimatur of the corporation to the suit. So understood it would appear that once winning such stockholder approval that the application of the loser pays rule should be as against the corporation on whose behalf the suit is prosecuted and not any individual shareholder.

\section{E. Information contraints}

Professor Dario Latella echos the concerns of other symposium commentators: "there is no efficient derivative suit without a full, penetrating and preliminary information" bearing on the facts underlying the derivative suit. ${ }^{27}$ The lack of shareholder access to information that would enable the derivative suit to move forward was identified as a major weakness confronting the derivative suit plaintiff. ${ }^{28}$ Ownership of shares in a U.S. company carries with it rights to access the books and records of the company. To be sure, such

24 See generally Charles M. Yablon, The Good, The Bad, and the Frivolous Case: An Essay on Probability and Rule 11, 44 UCLA L. Rev. 65 (1996)(reviewing Federal Rule of Civil Procedure 11 which authorizes assignment of costs and concluding the standards for doing so should reflect the social benefits of permitting long-shot suits).

25 See e. g., Pelletier v. Zweifel, 921 F.2d 1465 (11 ${ }^{\text {th }}$ Cir. 1991)(awarded where no basis in fact for the complaint and suit was continued in the face of several warnings from the court as to the possibility of a sanction being imposed).

26 See e. g., Mills v. Electric Auto-Lite Co., 396 U.S. 375 (1970); Tandycrafts, Inc. v. Initio Partners, 562 A.2d 1162 (Del. 1989).

27 Latella note 3 supra at 16.

28 See Giudici, note supra at 9-10; Kalss note supra at 21; Reisberg note supra at 16-17. 
access is conditioned on the requesting shareholder establishing a proper purpose for inspecting company documents. A proper purpose exists when access is sought to determine whether there has been mismanagement or misconduct on the part of company officials. ${ }^{29}$ In addition to shareholder inspection rights provided by state law, American procedure accords litigants expansive discovery procedures that enable litigants to gain access to information in their opponent's possession. On this point, it was significant that when the U.S. Congress in 1995 addressed concerns raised by accountants and high-tech companies that they too frequently were the targets of abusive securities litigation that Congress chose to amend the U.S. securities laws so that discovery pursuit to the suit could not occur until all defendants' pretrial motions had been resolved. Not surprisingly, following the passage of the Private Securities Litigation Reform Act of 1995, there was an increase in filing of securities fraud action in state courts to avoid the Reform Act's bar to discovery while various defendants'pretrial motions were pending. ${ }^{30}$

Shareholder information rights are a far larger concern than facilitating their initiating a derivative suit. The lack of traction in Europe on this issue suggests far greater problems confronting stockholders in European companies than enabling them to discipline managerial misconduct. To the outsider, such a restraint on owners challenges the very concept of the company, whether it be a private or a public one.

29 See e.g. Melzer v. CNET Networks, Inc., 934 A.2d 912 (Del. Ch. 2007)(while seeking access to books and records to investigate for mismanagement or wrongdoing, the request nonetheless must be accompanied by evidence supporting a credible basis from which the court can infer mismanagement, waste or wrongdoing may have occurred); Ihrig v. Frontier Equity Exchange Assoc., 128 P.3d 993 (Kan. Ct. App. 2006)(must establish by a preponderance of the evidence at an evidentiary hearing the possibility of mismanagement); See also Security First Corp. v. U.S. Die Casting and Dev. Co., 687 A.2d 563 (Del. 1997) (only access to those records the plaintiff has met its burden of showing by a preponderance of the evidence that there is probable wrongdoing and that the books and records are essential to the accomplishment of that stated purpose). But see Thomas \& Betts Corp. v. Leviton Mfg. Co., 681 A.2d 1026, 1031 (Del. 1996) (allegations of waste and mismanagement merely a subterfuge for real purpose of accessing stockholder list, which was to acquire control).

30 See SEC Office of General Counsel, Report to the President and the Congress on the First Year of Practice under the Private Securities Litigation Reform Act of 1995, [Current] Fed. Sec. L. Rep. (CCH) If 85,931 (April 1997); Randall S. Thomas \& Kenneth J. Martin, Using State Inspection Statutes for Discovery in General Securities Fraud Actions, 77 B.U. L. Rev. 69 (1997). 


\section{$F$. Conclusion-paving the way for the entrepreneurial lawyer}

In the movie Field of Dreams a disembodied voice instructed actor Kevin Costner that "if you build it they will come." So it will be for plaintiff-oriented law firms if a few changes in the law bearing on derivative suits can occur. As seen, the most formidable barrier is the loser pays regime. To be sure, this principle is deeply ingrained around the world. But the limitation makes little sense where the general meeting approves the suit. In such an instance, the suit bears the imprimatur of the company; at least on this point stockholders should have some right to determine whether to commit themselves collectively behind the suit. Such approval need not be so formidable if the issue is examined closely. If the suit is against the dominant stockholder or directors nominated by such a holder, then it should be a short step to believe the appropriate approval sought be disinterested. Thus, the approval could be that of a majority of the minority. In the private company, the American experience should invite what is gained by distinguishing between individual and company causes of actions when the focus of the suit is one faction of the company against the other. Here we can envision all suits being individual suits. This does not address the loser pays concerns which will likely discourage many reasonably-based suits from being pressed. If reform of the loser pays rule is to occur then perhaps it might occur by focusing on whether the suit appeared abusive or otherwise misguided. This would replace an automatic assignment of costs with a more reasoned and deliberate one.

But movement on expanding information rights to stockholders is, as several commentators in this symposium have expressed, also necessary. With shareholder activism on the rise around the globe, it would seem now is a particularly good time for legislative bodies to reflect on basic features of ownership. Certainly one would believe information bearing on management's stewardship of the firm would be a central feature of ownership.

These two changes would likely attract attorneys who would evaluate the risk of any particular suit within a context of a portfolio of suits being prosecuted by that attorney. Thus, the derivative suit would be harnessed not just to an entrepreneurial lawyer, but a risk preferring one. If this should occur, corporate ownership would not the be the same thereafter. But shareholders would never want it to return to its former self. 